\title{
UPAYA GURU DALAM MENGEMBANGKAN KEMAMPUAN MEMBACA MENULIS PERMULAAN SISWA KELAS I MI
}

\author{
Herisfani Fauziah \\ Sekolah Khusus Bhakti Putera Cisauk Tanggerang \\ Griya Serpong Asri Blok Catalia, Suradita, Cisauk, Tangerang, Banten 15343 \\ e-mail: herisfina14fauziah@gmail.com
}

\begin{abstract}
The purpose of this reaserch is to find out how the teacher's efforts in developing beginning reading and writing skill of first grade students. This study also aims to determine what obstacles faced by teachers in developing beginning reading and writing skill of first grade students. The method used in this research is descriptive qualitative research method where data collection using interview technique, observation and documentation. In this study the authors interviewed several sources including: the headmaster of MI Nurul Falah Suradita and two teachers of MI Nurul Falah Suradita. The result of the research shows that the teacher's effort in developing beginning reading and writing skill in the first class is by giving additional tutorial, giving the reading book, using the study time well, dictating the students, using Spell reading method and reading fluently, giving motivation, giving reward, giving guidance and supervision, bringing to the library and assessing. And the obstacles of teachers in developing beginning reading and writing skill are less conducive learning and limited textbooks.
\end{abstract}

Keywords: Developing, Beginning Reading, beginning Writing

\begin{abstract}
Abstrak
Tujuan penelitian ini adalah untuk mengetahui bagaimana upaya guru dalam mengembangkan kemampuan membaca menulis permulaan siswa di kelas I. Penelitian ini juga bertujuan untuk mengetahui hambatan apa saja yang dihadapi guru dalam mengembangkan kemampuan membaca menulis permulaan siswa kelas I. Metode yang digunakan dalam penelitian ini adalah metode penelitian kualitatif deskriptif di mana pengumpulan data menggunakan teknik wawancara, observasi dan dokumentasi. Dalam penelitian ini penulis mewawancarai beberapa sumber diantaranya: Kepala Sekolah MI Nurul Falah Suradita dan dua orang guru wali kelas I MI Nurul Falah Suradita. Hasil penelitian menunjukkan bahwa upaya guru dalam mengembangkan kemampuan membaca menulis permulaan di kelas I diantaranya yaitu dengan memberikan les tambahan, memberikan buku bacaan, memanfaatkan waktu belajar dengan baik, mendikte siswa, menggunakan metode membaca Eja dan membacalancar, memberikan motivasi, memberikan reward, memberikan bimbingan dan pengawasan, mengajak ke perpustakaan dan memberikan penilaian. Dan yang menjadi hambatan guru dalam mengembangkan kemampuan membaca menulis permulaan yaitu susana kelas yang kurang kondusif dan terbatasnya buku pelajaran.
\end{abstract}

Kata Kunci: Pengembangan, Membaca, Menulis, Permulaan 


\section{Pendahuluan}

Keterampilan berbahasa yang harus dimiliki siswa antara lain keterampilan membaca, menulis, menyimak dan berbicara. Siswa harus bisa menguasai keterampilan berbahasa, membaca, menulis, menyimak dan berbicara dengan baik, terutama pada tingkat kelas rendah yaitu kelas I. Guru harus bisa berusaha penuh memainkan perannya agar siswa memiliki kemampuankemampuan tersebut, terutama kemampuan membaca dan menulis. Kemampuan membaca dan menulis di kelas I lebih sering disebut dengan membaca menulis permulaan. Hal ini disebabkan kelas I merupakan kelas awal atau permulaan bagi siswa untuk belajar membaca dan menulis yang lebih intens.

Membaca merupakan salah satu keterampilan terpenting bagi anakanak. Namun banyak anak-anak tidak mendapatkan pembelajaran membaca secara memadai. ${ }^{1}$ Karena belajar membaca merupakan awal bagi mereka mengenal proses belajar mengajar yang sistematis. Oleh karena itu sudah sepatutnya ada dorongan dari guru maupun orang tua ${ }^{2}$ untuk mendorong anak belajar membaca dan menjadikan anak menjadi anak yang gemar membaca. Karena jika seseorang memiliki hobi membaca maka ia akan menjadi orang yang berwawasan luas dan akan memiliki pemikiran yang luas pula. Selain membaca, menulis juga merupakan salah satu keterampilan yang tidak kalah penting. Menulis merupakan bentuk komunikasi untuk menyampaikan ide melalui bahasa tulis.Untuk menyampaikan ide tersebut, anak harus dibimbing dan diajar menulis sejak dini.

${ }^{1}$ Annika Agelii Genlott dan Ake Gronlund, "Improving literacy skills through learning reading by writing: The iWTR method presented and tested," Jurnal Computer \& Education 67 (2013): 98.

2 Olena V. Vasylenko, "The Parents' Role in Helping Children to Develop Reading Skills," Scientific Articles EETP 12, no. 4 (2017): 71-80.
Di keas I ini, siswa memasuki fase awal sekolah yang memang membutuhkan kesiapan baik secara fisik maupun psikis. ${ }^{3}$ Dalam pembelajaran di kelas I, membaca dan menulis merupakan kemampuankemampuan yang memang harus dimiliki siswa. Karena di setiap buku pelajaran yang dimiliki siswa pasti terdapat bacaan ataupun tulisan-tulisan yang nantinya harus dibaca dan dipahami oleh siswa. Apabila siswa sudah bisa membaca dan menulis, maka akan lebih mudah bagi mereka menguasai materi pelajaran dan memahami setiap bacaan yang dibacanya. Oleh karena itu, perlu adanya usaha atau upaya dari guru agar anak didiknya bisa menguasai kemampuan membaca dan menulis, khususnya membaca dan menulis permulaan di kelas I. Guru dapat menerapkan metode-metode tertentu dan membuat pembelajaran di kelas menjadi pembelajaran yang menyenangkan dengan meyiapkan berbagai media belajar untuk mengembangkan kemampuan membaca dan menulis siswa. Hal ini bertujuan agar siswa tidak merasa bosan ketika belajar membaca maupun menulis.

Dalam proses belajar mengajar disekolah, setiap guru sangat mengharapkan agar siswa-siswanya dapat mencapai hasil belajar sebaik-baiknya. Pada kenyataannya banyak siswa di kelas I yang menunjukkan gejala tidak dapat mencapai hasil belajar sebagaimana diharapkan. Beberapa siswa masih menunjukkan nilai yang rendah dan sulitnya memahami materi pelajaran.

Pada tahun 2016-2017 MI Nurul Falah Suradita memiliki 120 siswa yang duduk di kelas I. Lima puluh persen dari siswa kelas I masih memiliki kemampuan membaca menulis permulaan yang rendah dan harus dikembangkan dan dibimbing lagi. ${ }^{4} \mathrm{Hal}$ ini bisa terjadi karena tidak semua siswa di MI

${ }^{3}$ Zusy Aryanti, "KesiapanAnakSaat Memasuki Sekolah," Elementary: Jurnal Ilmiah Pendidikan Dasar 1, no. 2 (2015): 64-67.

${ }^{4}$ Wawancara dengan guru kelas I tanggal 24 Agustus 2017 
Nurul Falah Suradita memasuki tahapan TK yang biasanya sudah mengenal baca dan tulis.Ada perbedaan yang jelas dari anak yang masuk TK terlebih dahulu dengan yang tidak menempuh pendidikan TK dari segi kemampuan baca tulisnya.

Penyebab dari rendahnyakemampuan membaca menulis permulaan siswa dapat disebabkan oleh bermacam-macam faktor. Salah satunya kurangnya perhatian dan bimbingan belajar dari orang tua di rumah. Orang tua adalah pendidik utama bagi anak. Guru telah berusaha semaksimal mungkin memberikan bimbingan yang terbaik di sekolah. Namun jika orang tua tidak meneruskannya di rumah maka hasilnya akan sia-sia. Oleh karena itu, perlu adanya kerja sama yang baik antara orang tua dan guru agar anak dapat mencapai hasil belajar yang baik dan memiliki kemampuan membaca dan menulis yang baik.

Berbagai upaya telah dilakukan oleh guru, khususnya guru kelas I untuk mengembangkan kemampuan membaca dan menulis siswa di kelas I. Pentingnya bagi siswa untuk menguasai kemampuan membaca dan menulis di kelas I dan masih banyaknya siswa kelasI yang belum memiliki kemampuan membaca dan menulis permulaan yang baik, hal ini mendorog penulis untuk meneliti tentang "Upaya Guru dalam Mengembangkan Kemampuan Membaca Menulis Permulaan Siswa Kelas I MI Nurul Falah Suradita."

\section{Kerangka Teori}

\section{Kemampuan Membaca dan Menulis Permulaan (MMP)}

MMP merupakan program pembelajaran yang diorientasikan kepada kemampuan membaca dan menulis permulaan di kelas-kelas awal pada saat anak-anak mulai memasuki bangku sekolah. Disebut permulaan karena peralihan dari masa TK atau lingkungan rumah ke dunia sekolah merupakan hal yang baru bagi anak. Hal pertama yang diajarkan kepada anak pada awal-awal masa persekolahan tersebut adalah kemampuan membaca dan menulis. Pada masa ini, guru harus menjadi fasilitator bagi anak untuk mampu membaca dan menulis di tahap awal atau permulaan. ${ }^{5}$

Kemampuan membaca permulaan lebih diorientasikan pada kemampuan membaca tingkat dasar, yakni kemampuan melek huruf. Kemampuan melek huruf ini kemudian dapat ditingkatkan menuju kemampuan membaca tingkat lanjut, yakni melek wacana. Jadi ketika anak sudah dapat menguasai melek huruf, anak akan diajarkan untuk memahami sebuah wacana yang dibacanya. Sedangkan kemampuan menulis pada tingkat dasa/permulaan, pembelajaran menulis lebih diorientasikan pada kemampuan yang bersifat mekanik. Pada tahap ini, anak akan dilatih untuk menuliskan lambang -lambang yang akan memiliki sebuah makna dan anak juga dilatih untuk menuangkan gagasan atau pikiran serta perasaannya kedalam bentuk tulisan.

Kemampuan membaca yang diperoleh pada saat membaca permulaan akan berpengaruh terhadap kemampuan membaca lanjut. Kemampuan membaca permulaan mendasari kemampuan membaca selanjutnya.Membaca permulaan bertujuan untuk membina dasar-dasar mekanisme menbaca yaitu kemampuan mengasosiasikan huruf-huruf dengan bunyi bahasa yang diwakilinya, membina gerak mata saat membacadari kiri ke kanan, membaca kata-kata serta kalimat sederhana. Pengajaran membaca di kelas I dan II MI dikenal dengan nama membaca permulaan. Kriteria membaca permulaan antara lain mengenal huruf dan vocal, dapat menggabungkan huruf-huruf menjadi suku

5 Solchan T.W dkk, "Pendidikan bahasa Indonesia di SD" (Skripsi, Universitas Terbuka, 2009), 6.5-6.6. 
kata dan dapat mengejanya dengan baik, dapat menggabungkan suku kata menjadi kata, dan dapat menggabungkan kata menjadi kalimat dengan bacaan yang tepat dan benar. ${ }^{6}$

Jadi membaca menulis permulaan dikhususkan untuk anak-anak yang baru saja mengenal pembelajaran membaca dan menulis. Biasanya terjadi di kelas rendah tingkat sekolah dasar. Kemampuan membaca permulaan ini akan berpengaru terhadap kemampuan membaca lanjutan siswa-siswa sekolah dasar. Dan memang membutuhkan bimbingan penuh dari guru, karena membaca dan menulis adalah pelajaran yang akan berlanjut ketika anak memasuki kelas tinggi.

Tujuan membaca dan menulis permulaan pada dasarnya adalah memberikan bekal pengetahuan dan keterampilan kepada siswa untuk mengenalkan tentang teknik-teknik membaca dan menulis permulaan dan dapat mempraktikannya dengan benar. Secara terperinci, membaca menulis permulaan bertujuan sebagai berikut:

a. Memupuk dan mengembangkan kemampuan anak-anak untuk memahami dan mengenalkan cara membaca dan menulis yang benar.

b. Melatih dan mengembangkan kemampuan anak untuk menuliskan dan mengenal huruf.

c. Melatih dan mengembangkan kemampuan anak untuk mengubah tulisan menjadi bunyi bahasa.

d. Melatih dan mengembangkan kemampuan anak untuk menuliskan bunyibunyi yang didengarnya.

e. Melatih keterampilan anak untuk memahami kata-kata yang dibaca, didengar dan mengingatnya dengan baik.

${ }^{6}$ Abdul Razak, Membaca Pemahaman, Teori dan Aplikasi Pengajaran (Pekanbaru Riau: Autografi, 2005), 46. f. Melatih keterampilan anak untuk dapat menetapkan arti tertentu dari sebuah kata dalam suatu konteks. ${ }^{7}$

Berdasarkan tujuan-tujuan membaca menulis permulaan diatas dapatdisimpulkan bahwa tujuan utama dari membaca menulis permulaan adalah untuk melatih dan mengembangkan kemampuan anak dalam membaca menulis dengan mengenalkan huruf menjadi bunyi bahasa yang dituliskan dalam bentuk tulisan.

\section{Metode Pembelajaran MMP}

\section{a. Metode Eja}

Pembelajaran membaca dan menulis permulaan dengan metode ini memulai pengajarannya dengan memperkenalkan huruf-huruf secara alfabetis. Huruf-huruf tersebut dihafalkan dan dilafalkan anak sesuai dengan bunyinya menurut abjad. Sebagai contoh A/a, B/b, C/c, D/d dan seterusnya, dilafalkan sebagai [a], [be], [ce], [de], dan seterusnya. Kegiatan ini diikuti dengan latihan menulis lambang tulisan seperti a, b, c, d, dan seterusnya atau dengan huruf rangkai.

Setelah melalui tahapan ini, para siswa diajak untuk berkenalan dengan cara merangkaikan beberapa huruf yang sudah dikenalnya, misalnya :

b, a, d, u menjadi b-a = ba (dibaca atau dieja $/$ be-a/ $=[b a]$

$\mathrm{d}-\mathrm{u}=\mathrm{du}$ (dibaca atau dieja $/ \mathrm{de}-\mathrm{u} /=[\mathrm{du}]$

$\mathrm{ba}-\mathrm{du}=$ dilafalkan $/ \mathrm{badu} /{ }^{8}$

Proses ini sama dengan menulis permulaan, setelah anak-anak bisa menuliskan hurf-huruf lepas, kemudian dilanjutkan dengan belajar menulis rangkaian huruf yang berupa suku kata. Proses pembelajaran selanjutnya adalah pengenalan kalimat-kalimat sederhana,

${ }^{7}$ St.Y.Slamet, Dasar - Dasar Pembelajaran Bahasa dan Sastra Indonesia di Sekolah Dasar (Surakata: UNS Press, 2008), 77.

8 Solchan T.W dkk, "Pendidikan bahasa Indonesia di SD," 6.16. 
contoh-contoh perangkaian huruf menjadi menjadi suku kata, suku kata menadi kata, dan kata menjadi kalimat diupayakan mengikuti prinsip pendekatan spiral, pendekatan komunikatif, dan pengalaman berbahasa.

Agar memudahkan guru dalam mengajarkan MMP ini ke anak ada baiknya guru memberikan kata-kata yang ada di lingkungan anak dan sudah biasa didengar oleh anak. Jika metode ini tidak berhasil dilakukan oleh guru maka guru dapat mencoba metode yang lain dalam mengajarkan membaca dan menulis permulaan.

\section{b. Metode Bunyi}

Metode bunyi ini merupakan bagian dari metode eja. Prinsip dasar dan proses pembelajarannya tidak jauh beda dengan metode eja/abjad. Perbedaannya hanya terletak pada cara atau sistem pembacaan atau pelafalan abjad (huruf-hurufnya). Sebagai contoh :

Kata nani dapat dieja menjadi :

/en-a/ = [na]

/en-i/ = [ni] dibaca nani. ${ }^{9}$

\section{c. Metode Suku Kata}

Proses pembelajaran dengan metode ini diawali dengan pengenalan suku kata, seperti ba, bi, bu, be, bo/ca, ci, cu, ce, co/da, di, du, de, do/ ka, ki, ku, ke, ko/, dan seterusnya. Suku kata tersebut kemudian dirangkaikan menjadi kata-kata bermakna,seperti bo bi, bi - bi, ba - ca, cu - ci, ka - ca, da - da, du - ka, ka - ki, ku - da. Kegiatan ini dapat dilanjutkan dengan proses perangkaian kata menjadi kalimat sederhana. Seperti : ka - ki $\mathrm{ku}$ - da , ba - ca bu - ku, cu - ci ka - ki, proses selanjutnya yaitu proses pengupasan atau penguraian bentuk-bentuk tersebut menjadi satuan-satuan bahasaterkecil dibawahnya.

Jadi jika disimpulkan, dalam mengajarkan metode suku kata terdapat

\footnotetext{
${ }^{9}$ Solchan T.W dkk, 6.18.
}

4 proses, yaitu pengenalan suku-suku kata, perangkaian suku kata menjadi kata, perangkaian kata menjadi kalimat sederhana dan tahapan yang terakhir yaitu perangkaian dan pengupasan.

\section{d. Metode Kata}

Metode kata merupakan nama lain dari metode kupas rangkai yang ada didalam metode suku kata. Proses pembelajaran MMP dengan metode ini melibatkan serangkaian proses pengupasan dan perangkaian maka metode ini dikenaljuga sebagai metode kupas - rangkai. Sebagian orang menyebutnya metode kata atau metode kata lembaga.

\section{e. Metode Global}

Sebagian orang mengistilahkan metodeini denganmetodekalimat.Dikatakan demikian karena alur proses pembelajaran MMP yang diperlihatkan melalui metode ini diawali dengan penyajian beberapa kalimat secara global. Untuk membantu pengenalan kalimat yang dimaksud, biasanya digunakan gambar. Dibawah gambar tersebut dituliskan kalimat yang yang kira-kira merujuk pada gambar tersebut. ${ }^{10}$

Setelah anak diperkenalkan dengan beberapa kalimat, barulah proses pembelajaranMMPdimulai.Gurumengambil salah satu kalimat.Kalimat tersebut dijadikan dasar/alat untuk pembelajaran MMP. Melalui proses deglobalisasi (proses penguraian kalimat menjadi satuan-satuan yang lebih kecil yakni menjadi kata, suku kata dan huruf).

Jadi dalam metode global, guru membutuhkan gambar dalam mengajarkan MMP kepada anak.Gambar dapat menarik perhatian anak serta diharapkan dapat membuat anak menjadi pandai membaca dan menulis.

\section{f. Metode SAS}

SAS merupakan singkatan dari Struktural Analitik Sintetik. Metode SAS

\footnotetext{
${ }^{10}$ Solchan T.W dkk, 6.20-6.21.
} 
merupakan salah satu jenis metode yang bisa digunakan untuk proses pembelajaran membaca dan menulis permulaan bagi siswa pemula. Pembelajaran MMP dengan tahap ini mengawali pelajarannya dengan menampilkan dan memperkenalkan sebuah kalimatutuh. Mula-mula anak diperkenalkan dengan sebuah struktur yang memberi makna lengkap, yakni struktur kalimat. Hal ini dimaksudkan untuk membangun konsepkonsep kebermaknaan pada diri anak.

Kemudian melalui proses analitik, anak-anak diajarkan untuk mengenal konsep kata. Kalimat utuh yang dijadikan tonggak dasar untuk pembelajaran membaca permulaan ini diuraikan kedalam satuan-satuan bahasa yang lebih kecil yang disebut kata. ${ }^{11}$

Proses penguraian penganalisisan dalam pembelajaran MMP dengan metode SAS, meliputi :

1) Kalimat menjadi kata-kata

2) Kata menjadi suku kata

3) Suku kata menjadi huruf-huruf.

Jadi dapat dikatakan bahwa metode SAS ini merupakan metode yang menganalisis satuan terbesar yaitu kalimat kemudian diubah menjadi yang kecil yaitu kata, kemudian kata diubah menjadi suku kata dan mengubahnya lagi menjadi satuan yang paling kecil yaitu huruf.

\section{Metodologi Penelitian}

Dalam penelitian ini penulis menggunakan metode fenomenologi dengan pendekatan kualitatif. Pendekatan ini mengharuskan peneliti langsung berhadapan dengan responden untuk mengumpulkan data-data yang dibutuhkan. Setelah data-data terkumpul, penulis mendeskripsikannya kemudian diolah pada teknik analisis data.

Dalam penelitian ini terdapat tiga prosedur penelitian. Pertama, tahap orientasi (deskripsi). Pada tahap ini peneliti

\footnotetext{
${ }^{11}$ Solchan T.W dkk, 22.
}

mendeskripsikan apa yang dilihat, didengar, dirasakan dan ditanyakan. ${ }^{12}$ Pada tahapan ini, menggali informasi tentang sekolah dan juga peneliti mencatat segala permasalahan yang ada di sekolah berdasarkan apa yang dilihat, didengar dan dirasakan selama berada di lapangan.

Kedua, tahap reduksi / focus. Pada tahap ini, peneliti mereduksi segala informasi yang ditemukan pada tahap I unuk memfokuskan pada masalah tertentu. Dengan kata lain pada tahapan ini, peneliti memilih masalah mana yang yang dianggap menarik dan menjadikannya sebagai fokus penelitiannya. Pada penelitian ini difokuskan kepada guru.

Ketiga, tahap seleksi. Pada tahap ini peneliti menguraikan fokus yang telah ditetapkan menjadi lebih rinci. Dengan kata lain, peneliti menganalisis lebih dalam fokus penelitiannya dan membuatnya menjadi lebih rinci dan jelas. Pada penelitian ini fokus lebih dirinci menjadi upaya guru dalam mengembangkan kemampuan membaca menulis permulaan dan hambatan guru dalam mengembangkan kemampuan membaca menulis permulaan.dan setelah fokus ditentukan, peneliti mengumpulkan data berdasarkan fokus tersebut dan setelah itu menganalisis sehingga menghasilkan temuan - temuan pnelitian.

Mengenai lokasi, penelitian ini dilaksanakan di MI Nurul Falah Kecamatan Cisauk Kabupaten Tangerang. Secara keseluruhan, siswa dan siswiyang bersekolah di MI Nurul Falah berlatar belakang menengah ke atas yaitu rata-rata tingkat perekonomiannya dapat dikatakan cukup.

Secara geografis, madrasah ini berada dilingkungan pendidikan. MI ini bersebelahan dengan SDN Suradita Cisauk dan SDN Rahayu Cisauk. Fasilitas di sekolah ini dapat dikatakan belum lengkap atau

${ }^{12}$ Sugiyono, Metode Penelitian Kuantitatif, Kualitatif dan RED (Bandung: Alfabet, 2009), 21. 
mencukupi. Dapat dilihat dengan belum tersedianya laboratorium untuk IPA dan laboratorium komputer, serta ruangan kelas yang masih belum memadai. Peserta didik di MI Nurul Falah Cisauk berjumlah 325 anak. Jumlah guru yaitu 18 orang.

Pengumpulan data dilakukan dengan melaksanakan pengamatan (observasi), wawancara dan dokumentasi. Kemudian dalam proses analisis data, peneliti mengikuti langkah-langkah seperti yang dianjurkan oleh Miles dan Huberman yaitu aktifitas dalam analisis data kualitatif deilakukan secara interaktif dan berlangsung secara terus menerus sampai tuntas, sehingga datanya sudah jenuh. ${ }^{13}$ Adapun aktivitas dalam analisis data menurut Miles dan Huberman yaitu reduksi data, penyajian data dan pengambilan kesimpulan dan verifikasi.

\section{Hasil dan Pembahasan}

\section{Strategi Pengembangan Kemampuan Membaca Menulis Permulaan}

Berdasarkan hasil temuan penelitian di atas, diketahui terdapat beberapa upaya guru dalam mengembangkan kemampuan membaca menulis permulaan siswa berjalan dengan baik. Upaya-upaya guru dalam mengembangkan kemampuan membaca menulis permulaan siswa kelas I antara lain sebagai berikut :

\section{Mengondisikan kelas senyaman mungkin \\ Bagi seorang guru, kelas yang} nyaman dan bersih merupakan hal yang sangat penting. Kelas bisa ditata rapi sesuai dengan keinginan guru dan siswa.guru bisa berinovasi dengan mengubash susunan meja dan kursi siswa setiap seminggu sekali ataupun dengan membuat prakarya prakarya yang difungsikan untuk menghias kelasnya agar terlihat lebih bagus. Dan juga guru perlu membiasakan siswa untuk selalu menjaga kebersihan kelas agar ketika siswa

\footnotetext{
${ }^{13}$ Sugiyono, 276
}

belajar siswa merasa nyaman dan kelas menjadi bersih dan rapi.

Hal ini dapat dilihat di catatan observasi penelitian selama di kelas seperti berikut ini:

Sebelum memulai pelajaran guru meminta semua siswa untuk merapikan meja belajar dan tempat duduknya. " ayoo semua sekarang ibu minta rapikan meja dan bangku nya masing - masing, tolong luruskan mejanya dengan meja yang ada di depan." Perintah guru kepada semua siswa. ketika siwa - siswa yang lain dengan sigap merapikan mejanya masing - masing.

Setelahmelihatsemuamejadanbangku rapi, bu guru kembali memerintahkan siswa untuk mengambil sampah yang ada di kolong meja atau dibawah meja. " sekarang yang melihat sampah disekiar mejanya atau kolong mejanya tolong di buang ke tempat sampah!" perintah guru kembali. Dan siswa - siswa pun langsung membuang sampah - sampah disekitar meeka. “ okee bu guru kasih jempol dulu buat anak - anak ibu karna sudah merapikan kelas dan membersihkan kelas, kalau kelas kita rap dan bersih kita belajarnya juga jadi tenang dan nyaman."

Hal inilah yang selalu dilakukan oleh guru kelas I di MI Nurul Falah yang selalu mementingkatkan kebersihan kelasnya dengan selalu menyuruh siswa membersihkan kelas atau sampah yang berserakan di kelas sebelum siswa memulai pelajaran. Jika kela bersih dan rapi, maka kegiatan belajar mengajar pun akan menjadi baik dan siswa dan guru pun akan merasa nyaman. Upaya ini senada dengan apa yang Jason Barr maksud dengan positive classroom climate (iklim kelas yang positif) di mana prestasi siswa dapat dipengaruhi oleh 
suasana di dalam kelas. ${ }^{14}$

\section{Membangkitkan mood belajar siswa}

Guru bukan hanya memiliki tugas untuk mengajar di kelas. Tetapi, lebih dari itu, guru dituntut untuk dapat menciptakan suasanabelajaryangkreatifdandisenangioleh siswa.oleh kerena itu, guru harus memiliki kreatifitas yang tinggi ketika mengajar di kelas. Ketika belajar, sering sekali guru menemukan siswa - siswanya yang merasa jenuh atau bosan.Disinilah tugas guru untuk menciptakan dan membangkitkan mood belajar siswa agar siswa merasa semangat dan kembali siap untuk belajar.

Banyak cara yang dapat dilakukan oleh seorang guru dalam membangkitkan mood belajar siswanya salah satunya yaitu dengan melakukan senam didalam kelas yang diikuti oleh siswa - siswa didalam kelas. Senam ini dapat dilakukan sebelum memulai pelajaran ataupun dipertengahan proses pembelajaran ketika siswa sudah mulai jenuh dan bosan. Degan adanya usaha guru dalam membangkitkan mood belajar siswa, diharapkan dapat membuat siswa semakin siap untuk mengikuti pelajaran di kelas dan akan mendapatkan hasil belajar yang baik pula.

3. Membangun Konsentrasi Belajar dengan Permainan

Konsntrasi belajar merupakan salah satu faktor yang berpengaruh terhadap prestasi belajar seseorang. ${ }^{15}$ Ketika siswa berkonsentrasi penuh saat belajar, maka ia akan lebih mudah memahami isi pelajaran nya dan siswa akan lebih cepat memiliki kemampuan membaca dan menulis. Konsentrasi memang sangat dibuthkan oleh siswa ketika belajar membaca dan menulis. Terutama ketika belajar menulis dengan mendikte. Dibutuhkan konsentrasi penuh dari siswa untuk mendengarkan kata yang

\footnotetext{
14 Jason J. Barr, "Developing a Positive Classroom Climate," IDEA Paper, no. 61 (2016): 1.

15 Slameto, Belajar dan Faktor - Faktor yang Mempengaruhinya (Jakarta: Rineka Cipta, 2010), 86.
}

didikte oleh guru dan menuliskan menjadi huruf - huruf yang benar. Guru juga bisa melatihkonsentrasisiswadenganmemastikan ketika pembelajaran berlangsung siswa siswa tertib dan tidak mengobrol satu sama lain. Karena jika mengobrol dan bercanda, hal ini dapat mengganggu konsentrasi temannya yang lain.

Adapun cara lain yang bisa dilakukan oleh guru yaitu dengan permainan. Seperti yang dilakukan oleh guru kelas I di MI Nurul Falah yang memberikan permainan untuk melatih konsentrasi siswanya. Permainan dan bermain merupakan hal yang sangat dekat dengan anak terutama anakyang masih duduk di kelas I. dengan adanya pemainan ketika belajar, maka anak akan menjadi senang dan tidak merasa tertekan. Terlebih ketika permainan yang dipilih oleh guru adalah permainan yang bermanfaat dan dapat melatih dan meningkatkan konsentrasi siswa saat belajar. Khoirul Anam, dkk membuktikan bahwa pemilihan permainan yang tepat dapat meningkatkan konsentrasi belajar peserta didik. ${ }^{16}$

4. Membaca Nyaring

Membaca nyaring merupakan salah satubagian yang paling sering digunakanoleh guru khususnya guru di kelas rendah dalam mengajarkan membaca.membaca bersuara atau nyaring adalah kegiatan membaca dengan menyuarakan tulisan yang dibacanya dengan ucapan dan intonasi yang tepat, agar pendengar dan pembaca dapat menangkap informasi yang disampaikan oleh penulis. ${ }^{17}$ Jadi, pembelajaran membaca nyaring ini dilakukan oleh siswa dengan membaca cerita atau tulisan dengan mengeraskan suara mereka agar terdengar oleh temannya yang lain. Adapun manfaat dari membaca nyaring

16 Khoirul Anam, Purwadi, dan Anita Chandra, "Upaya Meningkatkan Kosentrasi Belajar Anak Melalui Bermain Papan Titian di TK Indria Desa Kutosari Kecamatan Gringsing Kabupaten Batang," Jurnal PAUDIA 6, no. 2 (2017): 99.

17 Kundharu Saddhono dan St.Y Slamet, Meningkatkan Keterampilan Berbahasa Indonesia (Bandung: Karya Putra Darwati, 2012), 83. 
ini antara lain untuk memberikan contoh pada siswa proses membaca yang positif, mengekspos siswa untuk memperkaya kosakatanya dan memberi siswa informasi baru. ${ }^{18}$ Dengan dibiasakan nya siswa untuk membaca nyaring diharapkan siswa dapat memperkaya kosakata dari apa yang dibacanya dan siswa dapat pula memahami isi bacaan yang dibacanya.

Guru diMINurulFalahmembiasakan siswa untuk membaca nyaring yaitu dengan cara embaca sebuah teks bacaan yang dibaca secara bersama - sama denga suara yang lantang ataupun dengan cara guru menunjuk seorang siswa untuk membaca nyaring dan temannya yang lain mendengarkan dan megoreksi bacaan teman yang sedang membaca.

\section{Membaca dan Bernyanyi}

Membaca sambil bernyanyi merupakansalahsatumetodeyang digunakan oleh guru di MI Nurul Falah Suradita untuk membuat siswa nya menjadi senang dan minat dengan kegiatan membaca guru ingin menunjukkan pada siswa bahwa membaca bukanlah kegiatan yang harus ditakuti dan bukanlah pelajaran yang sulit. Tetapi guru ingin menunjukkan bahwa membaca bisa dijadikan kegiatan yang asik dan menarik dengan menggabungkannya dengan sebuah nyanyian. Dengan adanya kegiatan membaca sambil bernyanyi ini, siswa sangat antusias mengikuti pembelajaran membaca dan diharapkan dapat meingkatkan kemampuan membaca siswa dan menjadikan siswa gemar untuk membaca. Hal ini senada dengan Ning Setio Wati yang menyatakan bahwa, dengan mendengarkan lagu, siswa menjadi terstimulus untuk meningkatkan kemampuan bahasanya. ${ }^{19}$

${ }^{18}$ Kundharu Saddhono dan St.Y Slamet, Meningkatkan Keterampilan Berbahasa Indonesia.

${ }^{19}$ Ning Setio Wati, "Pengaruh Stimulasi Mendengarkan Lagu Dan Bernyayi Terhadap Perkembangan Berbahasa Pada Anak Usia Dini," Elementary: Jurnal Ilmiah Pendidikan Dasar 4, no. 1 (2018): 75-84.

\section{Memberikan Pujian}

Pujian merupakan salah satu hadiah atau ganjaran berupa kata - kata yang baik dan yang sangat mudah diberikan kepada orang lain. Guru memberikan pujian pada siswa yang telah membaca atau menulis dengan baik dan semangat. Adapun tujuan guru memberikan pujian pada siswa nya yaitu untuk membangkitkan semangat siswa dalam belajar dan untuk menghargai hasil kerja siswanya.Kalimat - kalimat yang diberikan oleh guru di kelas I MI Nurul Falah Suradita bermacam-macam bentuknya. Diantaranya guru memberikan pujian berupa tepuk hebat dan memberikan jempol yang biasanya diberikan saat siswa bisa menjawab pertanyaan dari guru ataupun disaat siswa bisa membaca dan menulis dengan baik dan semangat.Dan juga mengucapkan kata berupa pintar dan hebat.Dengan adanya pujian yang diberikan oleh guru, siswa akan merasa senang dan lebih semangat dalam belajar membaca dan menulis.

7. Memberikan semangat

Selain memberikan pujian untuk siswa - siswanya, guru juga perlu memberikan semangat atau kata - kata penyemangat untuk siswanya. Hal ini dimaksudkan agar iswa merasa lebih semangat dan merasa diperhatikan oleh gurunya. Ketika siswa belum bisa melakukan sesuatu sesuai harapan guru, maka perlulah guru untuk menyemagati siswanya. Guru tidak perlu menjudge siswanya ketika belum bisa membaca ataupun menulis, karena hal tersebut tidak akan membantu siswa untuk berkembang lebih baik lagi.

Adapun kalimat - kalimat penyemangat yang selalu diberikan oleh guru di MI Nurul Falah Suradita antara lain yaitu dengan mengatakan Nah itu bisa, ayoo pasti bisa. Kalimat - kalimat seperti itu diberikan oleh guru untuk membangkitkan semangat siswanya untuk terus belajar membaca dan menulis. 
8. Membiasakan Melafalkan Huruf Bacaan

Ketika guru mengajarkan menulis dengan cara mendikte pada anak, guru selalu menyuruh siswa - siswa nya untuk menyebutkan huruf - huruf pada bacaan yang didikte sebelum siswa menuliskannya di buku tulis mereka. Melafalkan huruf bacaan ini dilakukan oleh siswa dengan maksud agar siswa dapat menyebutkan huruf - huruf yang ada pada suatu kata yang akan ditulisnya dan akan memudahkan siswa ketika akan menulis. Dengan melafalkan huruf - huruf sebelum menulis, maka akan mengurangi kesalahan iswa akan menulis. Selain itu, siswa juga jadi lebih mengingat huruf - huruf alphabet beserta bentuk dan bunyi huruf tersebut.

Pada saat siswa baru memulai belajar membaca dan menulis khususnya pada tingkatan kelas rendah di SD hal ini perlu dilakukan.Hal ini bisa membantu guru untuk terus meningkatkan kemampuan membaca dan menulis siswanya. Walaupun terkadang bagi siswa yang sudah mulai bisa membaca dan menulis dengan baik cara seperti ini sangat membosankan, tetapi bagi siswa yang kemampuan membaca dan menulisnya masih rendah cara seperti ini sangatlah membantu.

9. Mengajarkan dengan Benda Konkret

Benda konkret adalah benda nyata atau terlihat disekitar siswa.Guru memberikan benda - benda yang ada disekitarnya untuk dieja atau ditulis oleh siswa. cara ini diberikan oleh guru untuk siswa yang kemampuan bacanya belum baik. Pemberian kata dri benda - benda konkret diberikan guru untuk mempermudah siswa ketika mengeja karena biasanya benda konkret yang ada belum terlalu susah untuk dibaca atau ditulis oleh siswa. benda - benda konkret yang dibawa oleh guru biasanya benda yang memiliki ejaan yang terdiri dari dua suku kata terlebiih dahulu. Jika siswa langsung diberikan benda yang terdiri dari dua atau lebih suku kata maka akan mempersulit siswa untuk cepat membaca ataupun menulis.

Maka dari itu, diperlukan waktu dari guru untuk lebih memfokuskan kepada siswa yang belum bisa membaca ataupun menulis dan mengajarkan siswa dari hal atau benda - benda sekitar yang diketahui oleh siswa.

\section{Hambatan dalam Mengembangkan Ke- mampuan Membaca Menulis Permulaan}

Dari hasil temuan - temuan di atas, terdapat beberapa hambatan yang dihadapi guru dalam mengembangkan kemampuan membaca menulis permulaan siswa kelas I. Diantaranya sebagai berikut:

1. Suasana belajar yang kurang kondusif

Suasana kelas ketika belajar menjadi penentu keberhasilan sebuah pembelajaran. Karenajika suasana tenang, maka konsentrasi siswa pun akan bagus dan memungkinkan hasil belajar yang bagus pula. Tetapi jika suasana belajar kurang kondusif, maka pembelajaran pun akan terganggu. Gangguan - gangguan yang menyebabkan suasana belajar menjadi kurang kondusif ini pun disebabkan oleh siswa didalam kelas itu sendiri. Misalnya, siswa berjalan - jalan ketika guru sedang menerangkan pelajaran, siswa mengobrol dan bercanda ketika guru menerangkan pelajaran dan ketika sedang membaca bersama - sama, siswa makan di kelas ketika jam pelajaran, siswa yang saling mencontek ketika sedang dikte, siswa yang mengganggu temannya ketika mengerjakan tugas.

2. Terbatasnya Buku Pelajaran

Buku pelajaran menjadi hal penting karena merupakan salah satu sumber belajar. Tetapi, jika sekolah belum memiliki buku pelajaran yang memadai maka akan menjadi sebuah hambatan bagi guru dalam menyampaikan materi pelajaran. Dan siswa pun akan kesulitan dalam mempelajari pelajaran. Buku pelajaran menjadi kendala 
d sekolah ini, buku paket pelajaran yangh dimiliki siswa hanyalah dalam bentuk buku LKS yang didalamnya terdapat materi pelajaran tetapi tidak selengkap buku pelajaran atau buku paket yang biasa ditemukan.

Siswa di kelas I sangat antusias ketika melihat buku yang berwarna dan dipenuhi gambar.dan buku yang seperti ini yang akan menarik siswa untuk membaca. Tetapi, didalam buku LKS yang dimiliki siswa hanya bewarna hitam dan terdapat gambar yang jumlahnya tidak banyak.Hal ini bisa menimbulkan rendahnya minat siswa untuk membaca tulisan yang ada dibukunya.

\section{Kesimpulan}

Dari hasil penelitian yang telah dilakukan mengenai upaya guru dalam mengembangkan kemampuan memaca menulis permulaan siswa kelas I MI Nurul Falah Suradita dapat diambil kesimpulan sebagai berikut:

1. Upaya yang dilakukan guru kelas I MI Nurul Falah Suradita dalam mengembangkan kemampuan membaca menulis permulaan yaitu:mengondisikan kelas senyaman mungkin, membangun mood belajar siswa, melatih konsentrasi dengan permainan, membaca nyaring, membaca dan bernyanyi, memberikan pujian, memberikan semangat, membiasakan melafalkan huruf bacaan, mengajarkan dengan benda konkret.

2. Faktor yang menghambat upaya guru dalam mengembangkan kemampuan membaca menulis permulaan siswa kelas I MI Nurul Falah Suradita adalah suasana belajar yang kurang kondusif dan terbatasnya buku pelajaran

\section{Rekomendasi}

Berdasarkan hasil penelitian ini, direkomendasikan kepada para guru untuk melakukan evaluasi belajar khususnya evaluasi kemampuan membaca menulis yang juga seharusnya diketahui oleh orang tua. Jadi, orang tua dan guru bertemu untuk membahas perkembangan membaca menulis anak di kelas, dan bisa menemukan solusi terbaik jika terjadi masalah pada anak.

Kemudian, sekolah perlu mengadakan kegiatan rutin di sekolahnya yang berhubungan dengan kegiatan membaca dan menulis agar menarik perhatian siswa sekaligus dapat mengembangkan kemampuan baca tulis siswa.

Media belajar yang digunakan guru perlu dikembangkan lagi, khususnya media dalam belajar membaca dan menulis yang seharusnya bukan hanya buku. Guru bisa mengeksplor ide - ide kreatifnya dalam menentukan media belajar yang akan digunakan.

\section{Daftar Pustaka}

Abdul Razak. Membaca Pemahaman, Teori dan Aplikasi Pengajaran. Pekanbaru Riau: Autografi, 2005.

Annika Agelii Genlott, dan Ake Gronlund. "Improving literacy skills through learning reading by writing: The iWTR method presented and tested." Jurnal Computer \& Education 67 (2013).

Jason J. Barr. "Developing a Positive Classroom Climate." IDEA Paper, no. 61 (2016).

Khoirul Anam, Purwadi, dan Anita Chandra. “Upaya Meningkatkan Kosentrasi Belajar Anak Melalui Bermain Papan Titian di TK Indria Desa Kutosari Kecamatan Gringsing Kabupaten Batang." Jurnal PAUDIA 6, no. 2 (2017).

Kundharu Saddhono, dan St.Y Slamet. Meningkatkan Keterampilan Berbahasa Indonesia. Bandung: Karya Putra Darwati, 2012.

Ning Setio Wati. "Pengaruh Stimulasi 
Mendengarkan Lagu Dan Bernyayi Terhadap Perkembangan Berbahasa Pada Anak Usia Dini." Elementary: Jurnal Ilmiah Pendidikan Dasar 4, no. 1 (2018).

Olena V. Vasylenko. “The Parents' Role in Helping Children to Develop Reading Skills." Scientific Articles EETP 12, no. 4 (2017).

Slameto. Belajar dan Faktor - Faktor yang Mempengaruhinya. Jakarta: Rineka Cipta, 2010.

Solchan T.W dkk. "Pendidikan bahasa Indonesia di SD." Skripsi, Universitas Terbuka, 2009.

St.Y.Slamet. Dasar - Dasar Pembelajaran Bahasa dan Sastra Indonesia di Sekolah Dasar. Surakata: UNS Press, 2008.

Sugiyono. Metode Penelitian Kuantitatif, Kualitatif dan RED. Bandung: Alfabet, 2009.

Zusy Aryanti. "Kesiapan Anak Saat Memasuki Sekolah." Elementary: Jurnal Ilmiah Pendidikan Dasar 1, no. 2 (2015). 